Postgrad. Med. J. (1965), 41, 313

\title{
SOME BIOCHEMICAL ASPECTS OF THE MYOPATHIES
}

\author{
B. P. Hughes, B.Sc., Ph.D. \\ Department of Chemical Pathology, The National Hospital, Queen Square, W.C.1.
}

SEVERAL general accounts of the biochemistry of the myopathies have recently appeared (e.g. Dreyfus and Schapira, 1962; Schapira and Dreyfus, 1963; Pennington, 1964). Consequently this article will not attempt a comprehensive review of the subject but will rather treat certain topics in greater detail, especially those which may have significant practical implications, for instance the value of serum enzyme assays. A number of recent developments in the field will also be mentioned.

Despite the considerable volume of published work, elucidation of the fundamental biochemical abnormalities which underlie the degenerative changes seen in the primary myopathies remains an unsolved problem. A major difficulty has been to pick out an abnormality which is a specific accompaniment of a single disease process, even when it is a question of distinguishing between a primary myopathy and a neurogenic muscle disorder. In this last respect, however, some progress has resulted from a realisation that the finding of elevated serum activities of various tissue enzymes in some types of primary muscle disease serves to distinguish them fairly sharply from the secondary myopathies. The distinction is not always clear-cut, but is sufficiently marked to be of practical value, in particular for such purposes as the early diagnosis of Duchenne muscular dystrophy and for detecting carriers of the form which is inherited as a sex-linked recessive characteristic.

Examples of muscle disorders in which there appear to be specific biochemical changes are McArdle's syndrome and certain other diseases of carbohydrate metabolism.

Most of this article will be devoted to a discussion of these topics, but to provide the necessary biochemical background it is necessary to deal briefly with some of the less specific biochemical changes that occur.

\section{Changes in Creatine and Creatinine Metabolism}

It has been realised for more than 50 years that some muscle disorders are accompanied by an increased urinary output of creatine
(Levène and Kriszteller, 1909) and a decreased output of its anhydride creatinine.

It has been shown that creatine is stored $\overrightarrow{0}$ in the muscle as creatine phosphate but is $\overrightarrow{-}$ synthesised elsewhere. Production of creatine ${ }_{\odot}^{\omega}$ phosphate is mediated by the enzyme creatine-: adenosine triphosphate phosphotransferase, an 3 . enzyme, subsequently referred to by its trivial name, phosphocreatine kinase, which catalyses the following reaction:

Creatine $+\mathrm{ATP} \rightleftharpoons$ Creatine phosphate $+\mathrm{ADP}_{\omega}^{\sigma}$ the so-called Lohman reaction (Lohman, 1934). $\vec{\omega}$ Creatine is formed by the breakdown, probably음 spontaneous, of creatine phosphate. Whenmuscle degeneration occurs, capacity to store $_{\subseteq}$ creatine as the phosphate is reduced, whereas normally the rate of synthesis is maintained. The resultant creatinæmia provokes a creatipisuria when the renal threshold of this substanse is exceeded. On the other hand, since creatiningeo is formed from creatine phosphate the urinary output of creatinine falls. Because the creatin-o uria is chiefly a result of reduced muscle mass, it is a pretty non-specific accompaniment of $\cong$ muscle wasting and of little help in diagnosis; $\overrightarrow{\vec{B}}$ thus Van Pilsum and Wolin (1958) found a 3 marked creatinuria both in pseudohypertrophic? muscular dystrophy and in poliomyelitis.? Before leaving the topic of creatine metabolismo it may be noted that reversibility of the phosphocreatine kinase reaction provides a means by which ATP can be resynthesised: from creatine phosphate. As it now seems fairly윽 certain that ATP breakdown is the source of chemical energy needed for the functioning of the contractile system in muscle (e.g. Gergely, 1964) creatine phosphate and phosphocreatine kinase play an extremely important part in the ${ }_{\sigma}^{N}$ supply of energy.

\section{Muscle Enzymes}

Because an adequate supply of chemical energy is essential to the function of muscle, $\frac{0}{5}$ many investigators have compared the tissues concentrations of enzymes involved in energy production in normal and diseased muscle.

Figure 1 indicates schematically the way in $\vec{\Phi}$ which chemical energy in the form of ATP $\stackrel{\odot}{\odot}$ 


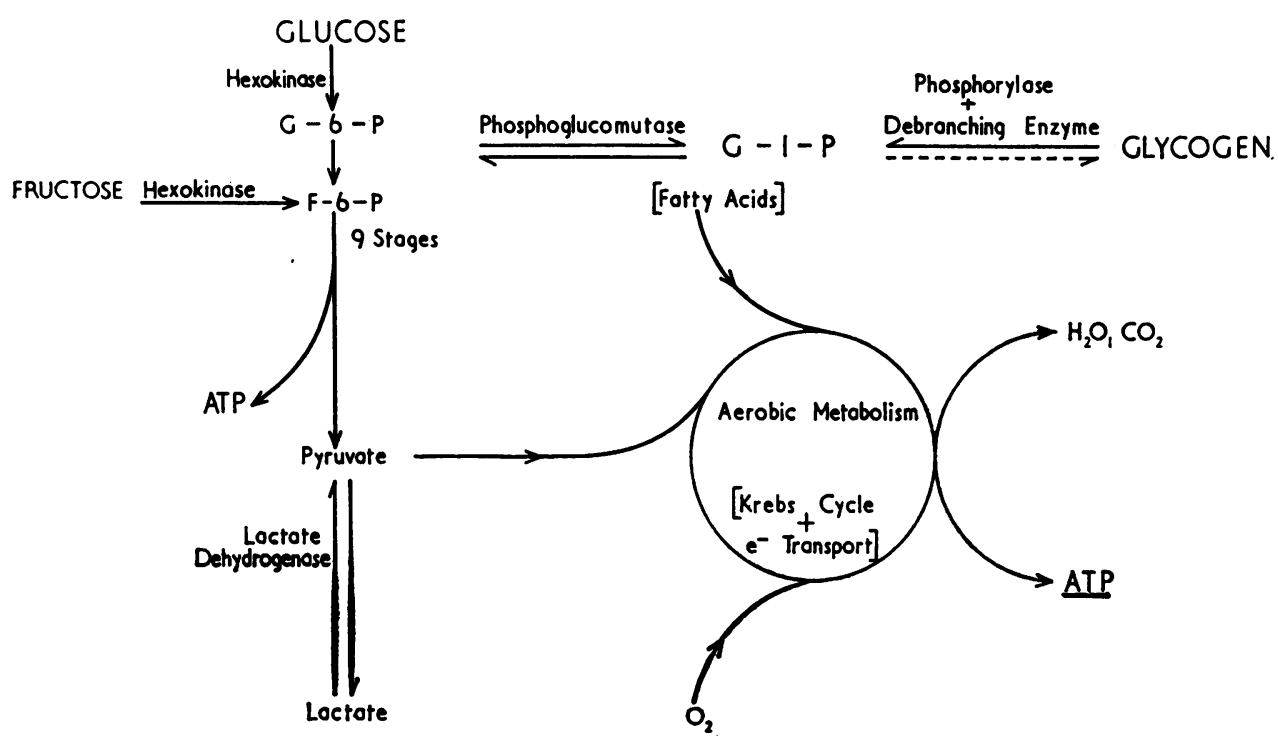

Fig. 1.-Sources of energy in muscle. A schematic representation of some major pathways for the production of ATP.

(adenosine triphosphate) is produced, starting with glycogen.

Glycagen is a highly branched molecule formed of glucose residues. The branches consist of glucose units joined together in the 1-4 positions (essentially a head-to-tail arrangement of the cyclic form of the glucose molecule). The branching points are produced by additional links in the 1-6 positions. The initial degradation of the structure to glucose 1-phosphate requires two enzymes, phosphorylase to attack 1-4 links as far as a branch point, and the debranching enzyme (amylo-1,6glucosidase) to attack the 1-6 links in order that further phosphorylase action can occur. As Fig. 1 indicates, glucose itself and fructose can also enter the pathway of anaerobic glycolysis (the Emden-Myerhof pathway).

Under conditions of maximal activity anaerobic breakdown of carbohydrate, i.e. muscle glycogen, to lactate supplies most of the energy, but in resting muscle, contrary to what was once thought to be the case, it seems likely that aerobic oxidation of fatty acids or lipids meets a good deal of the tissue energy requirements (e.g. Andres, Cader and Zierler, 1956; Fritz, Davis, Holtrop and Dundee, 1958; Bass and Hudlická, 1964).

If carbohydrate is fully oxidised much more ATP is produced per glucose residue than if metabolism is terminated at the pyruvate stage; thus on complete oxidation of a glucose resigure 38 molecules of ATP are produced, whereass if the process stops at pyruvate only 2 molectiog are formed (Slater, 1960). The aerobic process is thus energetically much more efficient, but may be limited during intense activity by the rate at which oxygen can be transferred to the site of ATP synthesis. Aerobic metabolism of carbohydrate and fatty acid requires the participation of the mitochondrion, in particular the mitochondrial electron transport systeno and terminates in reaction with oxygen trans ported within the cell by myoglobin. Because. of its greater efficiency, in muscles whose function is sustained moderate activity rather than short intense activity, the aerobic process predominates, whereas in short activity muscle the anaerobic phase may be more importane This is reflected in the increased numbers of mitochondria and increased concentration of oxidative enzymes in the former. In animals such as the rabbit, the different types of muscle, red and white, are clearly differentiated although the difference is really a statisticaf one depending on the relative amounts of mitochondria-rich red fibres, and white fibres poor in mitochondria but rich in enzymes suck as phosphorylase (Stein and Padykula, 1962)? In man the difference between muscles is lesฐ obvious, but the existence of the two fibro types has been demonstrated histochemicalls 
(Dubowitz and Pearce, 1960) and it is possible that their reactions to disease may be somewhat different, since in muscular dystrophy the fibres rich in oxidative enzymes tend to atrophy and the phosphorylase-rich fibres tend to be hypertrophied (Dubowitz and Pearce, 1961).

The capability of muscle to supply its energy requirements from anaerobic carbohydrate breakdown is one of its special biochemical features, so that the enzymes of the anaerobic phase of carbohydrate metabolism in normal and diseased muscle have received considerable attention, notably from Dreyfus, Schapira and their collaborators (e.g. Dreyfus, Schapira, Schapira and Demos, 1956). Other studies which may be cited are those of Vignos and Lefkowitz (1959), Ronzoni, Berg and Landau (1960) and the more recent extensive investigation of Heyck, Laudahn and Lüders (1963).

Before discussing the results of these investigations it must be pointed out that certain difficulties of interpretation beset measurements of tissue enzyme concentration if we want to know anything about the composition of the actual muscle. In muscle disease an increase, relative or absolute, in the concentration of connective tissue and fat frequently occurs and this would change the overall tissue composition even if the remaining muscle were normal, so that a reference base unaffected by such an increase is needed. Lilienthal, Zierler, Folk, Buka and Riley (1950) suggested noncollagen nitrogen as being suitable, and this suggestion has been widely adopted.

To summarise the results obtained by the investigators cited above we can say that several of the glycogenolytic enzymes referred to non-collagen nitrogen, and also overall glycolytic activity, are frequently reduced in primary myopathies perhaps to a third of their normal value (Dreyfus and Schapira, 1962), although Ronzoni and others (1960) found that hexokinase was little affected and that lactate dehydrogenase was actually increased. This latter finding is not however supported by the work of Heyck and others (1963). As to whether the various myopathies differed in the pattern of enzyme change accompanying them, results seem conflicting (c.f. Vignos and Lefkowitz, 1959 and Heyck and others, 1963). A possible source of confusion may have been the use of different clinical classifications. Besides being unable to differentiate clearly between the various primary myopathies the results of these investigations do not provide any clear distinction even between primary and secondary myopathies.

\section{Enzymes of oxidative metabolism}

Investigation of the enzymes of the oxidative phase of metabolism e.g. succinate dehydrogenase, cytochrome oxidase, have revealed little or no change, when analyses have been referred to non-collagen nitrogen (Dreyfus and Schapira, 1962). This is rather surprising in view of the fact that electron microscope studies (e.g. Van Breemen, 1960; Pearce, 1963), have shown considerable mitochondrial abnormality and destruction, and many of the oxidative enzymes are considered to be located within the mitochondria.

\section{Isoenzymes in muscle disease}

Isoenzymes are different proteins which have similar, but not necessarily identical, enzymic activity. In muscle disease most attention has so far centred around the lactate dehydrogenase isoenzymes which may be readily separated by electrophoresis, on agar for example (Wieme, 1959), and which may also be distinguished by differences in their enzymic behaviour (Plummer, Elliott, Cooke and Wilkinson, 1963; Dawson, Goodfriend and Kaplan, 1964). In normal human skeletal muscle 5 isoenzymes can be distinguished which are referred to as LDH1-5 in order of decreasing anodic mobility. In some mature muscles at least the slow moving isoenzymes usually predominate, whereas in human foetal muscle and in animal red muscle chiefly the fast moving enzymes are found. Various authors (e.g. Dreyfus, Demos, Schapira and Schapira, 1962; Lauryssens, Lauryssens and Zondag, 1964) have found that the electrophoretic pattern of isoenzymes from patients with Duchenne muscular dystrophy resembles that of the foetus, and recently Emery (1964) has reported loss of slow-moving isoenzymes in female carriers of the disease. Dreyfus and others (1962) suggested that this indicates a failure of maturation. However other workers (Lauryssens and others, 1963; Brody, 1964) have found similar abnormalities in human neurogenic atrophy as well as in primary muscle disease, and Brody (1964) has demonstrated a progressive change following experimental denervation in the guinea pig. Dawson and others (1964) by a different technique have also shown similar changes following denervation in the rabbit. At the moment, therefore, it seems likely that the change is a largely non-specific reaction of the tissue to metabolic or functional disturbance, and according to some authors (Lauryssens and others, 1963; Dawson and others, 1964) may 
reflect a decline in anaerobic glycolysis. However this field of investigation is now very active and the question cannot be regarded as settled.

It is worth noting that comparison of normal and diseased human muscle must be interpreted with caution since Dawson and others (1964) have shown considerable differences between normal muscles in their content of the various types of lactate dehydrogenase.

\section{Other Abnormalities}

In addition to the topics mentioned above numerous other biochemical abnormalities have been described in diseased muscle, some perhaps of very considerable importance for understanding the degenerative process, an example being the marked increase of various hydrolytic enzymes. Nevertheless since many of these are discussed in the reviews cited already, they will not be considered further. However one recent observation of considerable interest has been described by Watts and Hooton (1965) who found that a purified phosphocreatine kinase derived from dystrophic mice, despite having the same electrophoretic properties as the enzyme from normal animals, was only half as active. Phosphocreatine kinase possesses two sulphydryl groups (-SH) in the molecule which are concerned with activity and, as a possible explanation for their results, these authors suggested that one of the -SH groups might be inactivated in vivo. Since a number of enzymes, including myosin ATPase, require intact sulphydryl groups for activity, any increased tendency towards SH inactivation might have profound metabolic consequences, and it will be of great interest to see if future work confirms such a possibility in the mouse disease and in human myopathies.

\section{Familial Periodic Paralysis}

Recent accounts of the biochemical changes found in both hypo-and hyperkalæmic familial periodic paralysis have been given by McArdle (1964) and by Pearson (1964), so that these biochemically interesting conditions will not be discussed here.

\section{Defects of Muscle Glycogen Metabolism Myophosphorylase deficiency \\ (McArdle's syndrome)}

McArdle (1951) reported the case of a man, aged 30, who since childhood had suffered muscle pain, weakness and stiffness brought on by slight exercise. On investigation no rise in blood lactate or pyruvate following exercise could be detected, particularly after ischæmic exercise of the forearm muscles, when a 3 to 4-fold rise is normal. Several other cases with similar but not identical, clinical and bio? chemical signs have been described (Schmidand Mahler, 1959; Mommaerts, Illingworth $\overrightarrow{\tilde{\sigma}^{2}}$ Pearson, Guillory and Seraydarian, $1959 \%$ Schmid and Hamaker, 1961; Mellick, Mahles and Hughes, 1962; Thomson, McLaurin and Prinias, 1963; Rowland, Fahn and Schottland $\mathbb{0}$ 1963; Hockaday, Downey and Mottram, 1964) Additional features in some cases were myoglobinuria after excercise (Schmid and Mahler, 1959; Schmid and Hamaker, 1961 $\overrightarrow{\vec{*}}$ Rowland and others, 1963), and the late development of a limb girdle myopathy (Schmidg and Mahler, 1959; Schmid and Hamaker, 1961) 3 . In all individuals who were tested for this enzyme, there was a severe myophosphorylase deficiency, possibly a complete absence in the majority, as shown by various techniques e.giv biochemical, histochemical and immunologicake In addition to phosphorylase deficiency mos? patients had excessive amounts of glycogen intheir muscles.

The phosphorylase deficiency appeared to be confined to muscle so that for example, epipeso phrine injection provoked the expected ixser in blood sugar indicating the presence of hepatio phosphorylase and normal mobilization of lizes glycogen. Reference to Fig. 1 shows thas phosphorylase together with the debranching enzyme brings about the initial stage of glycogenolysis, so that its absence blocks the process and interferes with energy production from anaerobic glycolysis. Utilization of glucose (or fructose) and fatty acids is unaffected, se that slight or moderate muscular activity can be sustained by glucose or fatty acids extractee from the blood; consequently many of thesepatients were able to walk slowly on levep. ground without restriction. Fast walking of running however was soon halted by severe discomfort and weakness. Excercise capabilities varied somewhat from patient to patient (c.f Mommaerts and others, 1969; Schmid an Mahler, 1959) and for the same patient fron day to day (McArdle, 1951; Mellick and others? 1962). This variability may possibly reflect differences in the efficiency with which blood sugar and fatty acids are utilized. In this connection it has been found that a short-term improvement in excercise tolerance can b. achieved by inducing hyperglycæmia by, foo example, oral or intravenous glucose and intravenous glucagon (Schmid and Mahlee 1959; Schmid and Hamaker, 1961; Mellic 
and others, 1962). Oral fructose may also have similar affect (Mellick and others, 1962; Thomson and others, 1963) but although it can directly enter the glycolytic pathway (Fig. 1) its precise mode of action is a matter of discussion (Opie, Evans and Renold, 1962; Wolf, 1962). Despite the theoretical possibility of resultant increased glycogen deposition in the muscle it has been proposed that patients should take oral fructose prior to unavoidable exertion (Mellick and others, 1962; McArdle, 1964), but this does not always seem to be effective (Hockaday and others, 1964).

The demonstration of the presence of excessive glycogen in conjunction with low or absent phosphorylase has important biochemical implications. Originally the phosphorylase reaction was considered to be reversible, and could therefore participate both in glycogen synthesis and breakdown. Although under the conditions used for assaying the enzyme in vitro this is true (e.g. Sutherland and Wosilait, 1956), under physiological circumstances, glycogen synthesis is thought to take place by an irreversible process whereby glucose-1-phosphate and uridine triphosphate are converted to uridine diphosphate glucose and thence to glycogen, and which was first demonstrated by Leloir and Cardini (1957). It was later shown to occur in mammalian muscle by Robbins, Traut and Lipmann (1959). As various authors have pointed out (e.g. Larner and Villar-Palasi, 1959; Mommaerts and others, 1959) the excess glycogen usually present in McArdle's syndrome provides the strongest evidence for the independence of muscle glycogen synthesis and breakdown in man.

Although in some cases muscle phosphorylase seems to be entirely absent this may not always be so, thus in the case reported by Hockaday and others (1964) some inorganic phosphate was liberated when muscle homogenates were incubated with glucose-1-phosphate although much less than normal. Engel, Eyerman and Williams (1963) report two cases, brother and sister, with late development of symptoms and normal muscle glycogen in whom phosphorylase deficiency was complete in one individual but only partial in the other.

\section{Other diseases of glycogen metabolism}

Besides phosphorylase deficiency, other rare defects in glycogen metabolism have been reported, but only in some is muscle affected. These reports have been reviewed by Stetten and Stetten (1960) and also, for example, by Rowland and others (1963).
Before leaving the subject of the glycogen diseases it is worth noting that the simple measurement of venous lactate rise after ischaemic exercise of the forearm will usually yield valuable information for diagnostic purposes, and the finding of a normal result often helps to exclude the existence of a defect in anaerobic glycolysis which may sometimes be suggested by the clinical picture. Additional information as to whether any abnormality revealed in this way, is confined to muscle or is more general, can be obtained by testing the blood sugar response to epinephrine or glucagon.

Other rare specific enzyme abnormalities in muscle will doubtless come to light, but whether defects of this nature, not of course necessarily in the sphere of carbohydrate metabolism, will eventually be found in the more common myopathies cannot be foreseen. However, the existence of disorders such as the one just described lends some encouragement to the search.

\section{Serum Enzymes}

Sibley and Lehninger (1949) whilst carrying out a survey of serum aldolase levels in animal tissues noted that high serum levels were observed in two patients with progressive muscular dystrophy. This observation was later followed up by various authors (e.g. Dreyfus, Schapira and Schapira, 1958) who showed that besides aldolase, enzymes such as lactate dehydrogenase, LDH, aspartate aminotransferase, AspT (formerly GOT), alanine aminotransferase, AlT (formerly GPT) and a number of others were also often raised in muscular dystrophy and in the myosites, particularly acute dermatomyositis. By contrast in conditions involving neurogenic atrophy, even when rapid as in poliomyelitis, serum enzyme levels were normal or only transiently raised (Evans and Baker, 1957; White, 1959). Comparison of results for different enzymes indicated that serum aldolase levels were most consistently raised in primary muscle disease. The proportion of cases in whom abnormal levels were found varied according to their clinical classification, so that, for example, Thomson, Leyburn and Walton (1960) showed that all patients with muscular dystrophy of the Duchenne type with a sex-linked recessive mode of inheritance, except very advanced cases had grossly abnormal serum aldolase levels, whereas the proportion was smaller in limb-girdle cases and least of all in the facio-scapulo-humeral form; in myotonic dystrophy, serum levels were not always 
raised. Chung, Morton and Peters (1960) reported similar findings.

Of considerable interest was the observation of Thompson and others (1960) that in Duchenne muscular dystrophy the degree of aldolasemia diminished with age or duration of symptoms, and in advanced cases reached normal or near normal values. Although the evidence was less convincing, the same appeared to be true for the facio-scapulo-humeral form and for dystrophia myotonica, but for the limbgirdle form no such relationship between duration of symptoms and degree of aldolasemia existed.

An important advance in this field was made possible by the observation of Ebashi, Toyokura, Momoi and Sugita (1959) that serum phosphocreatine kinase levels were also greatly raised in muscular dystrophy patients. Results obtained by later workers (e.g. Dreyfus, Schapira and Demos, 1960; Hughes, 1962) fully confirmed this finding, and it has become apparent that there are certain advantages in using phosphocreatine kinase for the study of muscle disease. Firstly it is found to be a more sensitive index of muscle disease even than aldolase and it is also more specific. Thus, because it does not occur to any appreciable extent in liver, serum levels are not raised in liver disease, whereas aldolase may be grossly abnormal. A more important practical advantage follows from the fact that in man but not in some other species, the erythrocytes contain extremely little phosphocreatine kinase (Solvonuk, McRae and Collier, 1956) so that assays of activity in haemolysed specimens are possible in circumstances when aldolase values would be valueless. Data illustrating these points are given in Table 1.

Because of these advantages it is proposed to discuss serum enzyme findings in muscle disease chiefly in terms of phosphocreatine kinase, although whether phosphocreatine kinase is always the enzyme of choice may still be open to doubt. First however we must consider normal levels.

\section{Normal individuals}

Hughes (1962) reported that there was a statistically significant difference between the mean serum activities for normal men and women. This difference has not however been substantiated by other authors. Thus although Griffiths (1964) reports a rather higher mean activity for male children and adults, as compared with females, the differences were smaller and not statistically significant. Pearce, Pen-
TABLE 1

*Aldolase and Phosphocreatine Kinase (PCK尺 IN HAEMOLYSED SERUM FROM NORMAL INDIVIDUAL AND IN SERUM FROM PATIENTS WITH NON-MUSCULAR DISORDERS.

Infective hepatitis

Obstructive jaundice

Aspirin poisoning

Normal (haemolysed serum) F 20.1

Normal (haemolysed serum) F 18.4

Sex PCK

(I.U./litre) (DHA unitsf

Aldolase $\overrightarrow{\vec{B}}$

Units and normal ranges $(\bar{x} \pm 2 \sigma)$

Phosphocreatine kinase (PCK):

22.0

48.0

58.8

46.0

52.5

Units : International Units/litre of serum at 37

1 International Unit (I.U.) $=1 \mu$ mole creatine

liberated $/ \mathrm{min}$.

$1 \mu \mathrm{mole} / \mathrm{ml}$. $/ \mathrm{hr}$. $=16.7$ I.U. $/$ litre

Ranges: Males 10-67; Females 10-44

Aldolase :

Units: Dihydroxyacetone (DHA) units peis ml. of serum (Friedman and Lapan, 1958)

Range: Both sexes 4.0-21.0

* Data recalculated from Hughes (1963b) nington and Walton (1964a) in a smaller series again found no significant sex-difference. The mean values for women found by all these three authors, $1.5-1.7 \mu \mathrm{M} / \mathrm{ml}$./hr. (25-28 I.U./litre) were however in good agreement and the some-what higher value for males found by Huglese (1962), even if confirmed, would seldom $\overline{\text { Be }}$ of much practical significance.

The authors quoted above were all usi⿺辶 very similar technical methods for assaying the enzyme; other workers (e.g. Colombo, Rich terich and Rossi, 1962; Fowler and Pearson 1964) have used different techniques so that comparison of absolute values is not possible 3 However relative values found in normal subjects and in patients suffering from various? forms of muscle disease can be compared unless the comparisons are vitiated by the lowe. sensitivity of the method employed. Fowler: and Pearson (1964) admit that this may have been the case in connection with some of theiro earlier observations.

Various authors have reported increased? serum levels of a number of enzymes following exercise (e.g. Schlang, 1961; Halonen and Kont-ㅡㅡㄹ tinen, 1962) the rise being greater in untrained as compared with trained subjects (Fowler, Chowdbury, Pearson, Gardner and Bratton, 0 1962). If a substantial rise occurs after moder- $\omega$ ate exercise then obviously care needs to beo taken when interpreting results obtained ono uncontrolled subjects. Richterich, Rosin, Aebi and Rossi (1963) have reported that a marked? rise of phosphocreatine kinase may also occuro after exercise, but Hughes (1963a) and Pearce and others (1964a) were unable to demonstrate 
any increase after a relatively short period of vigorous exercise. However Hughes (1963a) suggested that prolonged periods of vigorous exercise might produce a moderate rise and also that apparently normal subjects may sometimes exhibit serum activities above the limit of normal. Except when the assay is being used for the detection of carriers of the sexlinked recessive form of muscular dystrophy it seems unlikely that these considerations will be of much practical importance.

\section{Duchenne muscular dystrophy}

The term Duchenne muscular dystrophy refers both to the type with the sex-linked recessive mode of inheritance and the usually rather more benign form, thought to be inherited as an autosomal recessive trait (Dubowitz, 1960; Walton, 1962).

In this form of the disease an extremely high percentage of patients show grossly elevated serum phosphocreatine kinase activities which in young patients may be more than 100 times the upper limit of normal (e.g. Dreyfus and Schapira, 1962; Hughes, 1963b; Pearce, Walton and Pennington, 1964b). Moreover in a number of cases elevated values have been observed in children before clinical signs of muscle disease had become apparent (Fowler and Pearson, 1964). The serum level falls as the disease progresses (Hughes, 1963b; Pearson and others, 1964) in a similar manner to that which had been demonstrated earlier for serum aldolase (Thomson and others (1960) but remains raised even in advanced cases. Data obtained by the present author are shown in Figure 2 .

\section{Limb-girdle muscular dystrophy}

In this form of muscular dystrophy the increase in serum enzyme levels is usually much less marked and while serum aldolase and phosphocreatine kinase are often elevated, normal values are also frequently found (Hughes, 1962; Pearce and others, 1964b), although serum phosphocreatine kinase seems to be raised more often. It is worth mentioning however that the author has observed a serum phosphocreatine kinase of 5050 I.U./1 in a boy of 15 diagnosed as suffering from limb-girdle dystrophy but who was only slightly affected clinically. His more severely affected elder sister, aged 23, had a serum enzyme activity of 362 units, a value much more typical of a limb-girdle case. Pearce and others (1964b) have also reported an unusually high value for a limb-girdle patient, aged 19 years, with a four year history, of $99.0 \mu \mathrm{M} . / \mathrm{ml} . / \mathrm{hr}$. (1650 I.U./

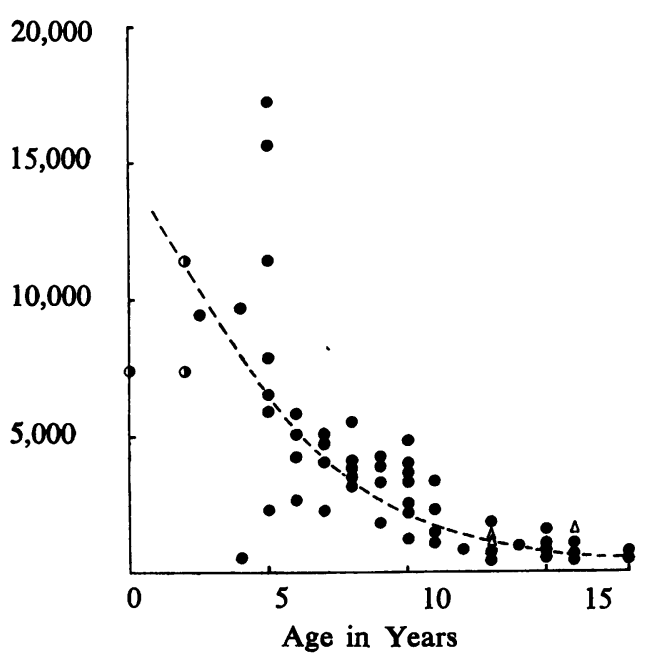

FIG. 2.-The relation between age and serum phosphocreatine kinase in Duchenne muscular dystrophy. Serum enzyme activities in 55 patients with Duchenne muscular dystrophy and in three suspected patients with absent or minimal clinical signs.

-Affected males

$\triangle$-Affected females

- Males with absent or minimal signs.

litre). The value of 5050 units is within the expected range for a typical young Duchenne patient, so that there may be more of an overlap between the two forms of muscular dystrophy as far as serum enzymes are concerned than is generally appreciated. A possible alternative explanation is that these cases were really comparatively benign examples of Duchenne muscular dystrophy with autosomal recessive inheritance.

No clear cut relationship seems to exist between age or duration of symptoms and the degree of enzyme elevation in limb-girdle dystrophy, at least for aldolase (Thomson and others, 1960) but possibly this is related to the more variable course of the disease and the existence of periods of apparent clinical arrest (Walton, 1964). Whether or not the observed enzyme activity gives an indication of prognosis, or perhaps of rate of progression at the time of assay, does not appear to have been investigated.

\section{Facio-scapulo-humeral muscular dystrophy}

Slight to moderate elevations of serum phosphocreatine kinase occur in the majority of cases, but again normal values are sometimes found (Pearce and others, 1964b). 


\section{Dystrophia myotonica}

Markedly raised levels of serum phosphocreatine kinase are seldom observed but a slight to moderate degree of elevation is frequently seen. Thus Pearce and others (1964b) report abnormal values in 4 out of 7 cases and $I$ have found the same in 4 out of 8 patients.

The proportion of patients showing abnormal values of serum phosphocreatine kinase may be greater than is found for other enzymes. Thus Thomson and others (1960) found only 2 out of 12 cases who showed a serum aldolase above the upper limit of normal.

\section{Ocular myopathy}

There appears to be little information about serum enzyme levels in this disorder. However, in serum examined in our laboratory from patients diagnosed as suffering from this condition, slight to moderate elevation was found in 4 out of 7 specimens.

\section{Polymyositis and dermatomyositis}

There are conflicting reports on the frequency with which raised serum values of phosphocreatine kinase are found in patients with various forms of polymyositis and dermatomyositis. Thus Pearce and others (1964b) find that the level is raised so infrequently in adults as to be of no diagnostic value. However Hughes (1962) has reported very high levels for phosphocreatine kinase and aldolase in two cases and Richterich and others (1963) claim that activities of as much as 500 times the upper limit of normal are encountered. Recently the author has observed a value of 17000 I.U./1. in a case of dermatomyositis which following steroid therapy fell to 28.5 units, i.e., well within normal limits (Table 1); and in a chronic case with a 4-year history who improved on treatment the enzyme level fell from just above normal limits in the pre-treatment period to a level again well within normal limits afterwards. Fowler and Pearson (1964) have presented data on successive serum phosphocreatine kinase estimations during the course of treatment and showed a progressive fall to normal limits. Pearson (1964) comments that both aldolase and creatine kinase are sensitive indicators of the disease process in acute polymyositis. Thus although there is no doubt that serum phosphocreatine kinase may be greatly elevated in cases of dermatomyositis and polymyositis, and in the author's limited experience some elevation is frequently found, its relative diagnostic efficiency as compared with, for example, aldolase, requires further study.
Fortunately as a means of assessing the effects of treatment it appears likely that any enzyme whose serum level is initially found to be raised may be employed. Thus besides. phosphocreatine kinase, serum AspT (de Moragas, Parry and Fleicher, 1957) and? aldolase (Thompson and Vignos, 1959; Gautie? and Richterich, 1963) have been shown to decline towards normal values when therapy is attended by clinical improvement, although improvement in muscle strength may followos normalization of the serum enzyme picture onlyafter an interval of 3 to 4 weeks and likewise. a subsequent rise may anticipate a clinical $\vec{\omega}_{\vec{\omega}}$ relapse by some weeks (Pearson, 1964).

\section{Thyroid disease}

Various workers (e.g. Griffiths, 1963; Saito, Hibi, Kawazura and Fukuyama, 1963) have reported that serum phosphocreatine kinase is ${ }_{\omega}^{\sigma}$ frequently elevated in hypothyroidism and $\frac{\omega}{\omega}$ returns to normal following replacement therapyo (Saito and others, 1963). This is of some interest as myopathic symptoms may be associated $\vec{c}$ with myxoedema (McArdle, 1964). Whether or not serum enzyme abnormalities are com- ${ }^{\mathbb{D}}$ monly found in hyperthyroid conditions dogs $\vec{\varnothing}$ not appear to have been systematically studie Unpublished observations of the author indicate however that normal values may observed in acute thyrotoxicosis with marked weakness, but are too few to permit any generalization.

\section{Neurogenic muscular atrophy}

Raised levels of serum enzymes, such as aldolase and the transaminases, are seldom a feature of disorders in which muscle weakness 음 or wasting is secondary to a neurogenic lesion (see for example Evans and Baker, 1957; $\frac{5}{3}$ Dreyfus, Schapira and Schapira, 1958). Hughes (1963b) and Pearson and others (1964b) have shown that the same is true of phosphocreatine kinase. However it should be noted that the 은 distinction between primary and secondary $\frac{D}{O}$ myopathies in this respect is not absolute. Hughes (1963b) presented data for three $\tilde{o}^{\circ}$ patients in whom serum phosphocreatine kinase was raised, in one by a substantial amount, $\mathcal{N}$ but in whom histological and other evidence $\omega$ strongly suggested denervation.

Further experience has confirmed the

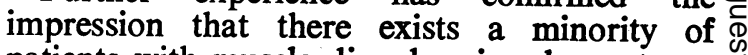
patients with muscle disorders in whom strong evidence of a neurogenic lesion exists, who 0 nevertheless show a serum enzyme elevation. $\frac{\vec{D}}{\mathbb{D}}$ Although no obvious common denominator is 
yet evident most of these patients exhibited unusual clinical features, whereas enzyme abnormalities in classical cases of neurogenic atrophy are rare. Of interest in this connection is a report by Chung and others (1960) of a patient with a myopathic electromyogram, neuropathic biopsy and fibrillation who showed a definite hyperaldolasemia and was considered to represent a mixed myopathy and CharcotMarie-Tooth disease.

The practical value of serum enzyme estimations in muscle disease can be summarised as follows:

(a) They provide a powerful means of early diagnosis of Duchenne muscular dystrophy even before clinical signs are apparent and, because elevations in neurogenic atrophy are relatively uncommon, allow a fairly certain differential diagnosis in young children between this condition and, for example, WerdnigHoffmann's disease. The ability to recognise early muscular dystrophy by allowing investigation of the first changes to occur in the muscle, before they are obscured by the proliferation of secondary changes, provides considerable hope that the essential genetic defect may eventually be uncovered. For this application, apart from phosphocreatine kinase, various enzymes are suitable and the choice can depend largely on convenience, provided their lower specificity is remembered.

(b) In other primary muscle diseases although serum enzyme determinations do not have such a decisive value, nevertheless in conjunction with the clinical evidence they can be of considerable help in arriving at a diagnosis. Whereas phosphocreatine kinase is probably the most sensitive index of muscle disease, this may not necessarily be so in the case of acquired myopathies i.e. the myosites.

(c) Successive enzyme estimations are useful in assessing the effect of therapy in polymyositis and dermatomyositis. Here again the choice of enzyme may often be one of convenience e.g. availability of a laboratory able to carry out the assay.

\section{Detection of Carriers of the Sex-linked Duchenne Muscular Dystrophy}

In 1960 Chung and others reported that a small proportion ( 3 out of 21) of certain carriers of the sex-linked Duchenne form of muscular dystrophy showed a raised serum aldolase activity; carriers of the limb-girdle form were quite normal in this respect. Schapira, Dreyfus, Schapira and Demos (1960) found that both aldolase and phosphocreatine kinase was raised in a proportion of the mothers of children with the sex-linked form and that raised values were found more often in cases where the family history was positive. Leyburn, Thomson and Walton (1961), however, were unable to detect any serum aldolase abnormalities in known and possible carriers.

Later work (e.g. Hughes, 1962, 1963a; Barwick, 1963; Richterich and others, 1963) confirmed the observation of Schapira and others (1960) that enzyme abnormalities were found sufficiently frequently to allow the detection of many Duchenne carriers by this means and indicated that phosphocreatine kinase was the most useful enzyme for the purpose. Although results obtained in various laboratories differ somewhat, it appears that $60-80 \%$ of certain or probable carriers of the sex-linked Duchenne muscular dystrophy exhibit a serum phosphocreatine kinase abnormality, but a minority are quite normal and cannot be detected in this way. Recently however Wilson, Evans and Carter (1965) using a more refined statistical treatment claim to be able to detect $90 \%$ of carriers on the basis of three separate assays on each individual. Although as a diagnostic test for the carrier state the enzyme assay is not completely successful, taken together with the known mode of inheritance, a reasonable assessment can be made of the risk that a female relative, a sister for example, is a carrier. It must be emphasised that because healthy individuals may occasionally show a transient rise of serum enzyme levels above the upper limit of normal, it is advisable to carry out the test on more than one occasion when the results are to be used to assist in genetic counselling (see also Wilson and others, 1965). Other abnormalities in addition to those of serum enzymes have been reported to be present in carriers, thus van den Bosch (1963) claimed that myopathic electromyographic changes could be demonstrated, and it has recently become clear that histological changes are sometimes found (Emery, 1963; Pearson, Fowler and Wright, 1963) and that occasionally clinical signs may be present (Emery, 1963). An explanation of these findings (Emery, 1964a; Pearson and others, 1963) has been suggested on the basis of the so-called Lyon hypothesis (Lyon, 1961) of the biologically inactive $\mathrm{X}$-chromosome.

By combining serum enzyme, histological, electrophysiological and other methods of investigation the proportion of carriers who can be reliably detected may prove to be considerably higher than is at present possible. 
Investigations on carriers of other types of muscular dystrophy have so far proved negative.

\section{General Considerations Arising From Serum Enzyme Abnormalities}

We have seen earlier that many tissue enzyme levels are low or normal in both primary and secondary muscle disease. This is certainly true of those enzymes most consistently found to have increased activity in the serum of myopathic patients. Assuming that the rate of clearance of a particular enzyme from the serum is not diminished then an increased outflow from the cell is indicated, and thus an increased permeability of the cell membrane, which seems to be particularly marked in muscular dystrophy of the Duchenne type and in acute dermatomyositis. By contrast, in neurogenic atrophy the permeability increase is at most slight.

The fact that the serum concentration of ussue enzymes falls as the disease progresses correlates quite closely with the amount of muscle which remains (Thompson and Vignos, 1959), although it is possible that outflow is also reduced when physical activity becomes restricted (Thomson, 1962) and that this is an additional factor.

Two general questions may be asked, firstly is the loss of tissue enzymes a major cause of degeneration, and, secondly, does the increased permeability of the cell membrane denote that the membrane is the site of the primary, genetically determined defect? Pennington (1964) has pointed that although not all the necessary information is available, the amount of aldolase lost from the affected muscle per day is probably only a very small fraction of the amount present. Consequently, although it may be a factor it is unlikely that tissue enzyme loss is, in itself, a major cause of degeneration. Whether or not a primary membrane defect is likely to be the ultimate cause of muscle degeneration in any of the mvopathies is open to argument since, as Zierler (1958) has shown, there is good evidence that disturbance caused by various factors such as anoxia, glucose lack and metabolic poisons can cause an increased outflow of intracellular enzymes. However, although it may be naïve to suppose that the serum enzyme findings denote the presence of a primary membrane defect, the importance of the various cellular membrane structures, e.g. the sarcolemma, the sarcoplasmic reticulum and the mitochondrial membranes, in the light of recent work on muscle biochemistry, and on the biochemistry of other cells, is such that a careful study of their chemical composition in health and disease and its relation to function might well throw valuable light on the ultimate nature of the disease process.

The author is a research fellow of the Muscular Dystrophy Group of Great Britain to whom he is indebted for financial support.

\section{REFERENCES}

Andres, R., CADER, G., and Zierler, K. L. (1956): Quantitatively Minor Role of Carbohydrate in Oxidative Metabolism by Skeletal Muscle in Intact Man in the Basal State: Measurement of $\mathrm{O}_{2}$ and Glucose Uptake and $\mathrm{CO}_{2}$ and Lactate Production in the Forearm, J. clin. Invest., 35, 671 .

BARWICK, D. D. (1963): Investigations of the Carrier State in the Duchenne Type of Dystrophy. Research in Muscular Dystrophy. The Proceedings of the Second Symposium January 1963, p. 10. London: Pitman Medical.

BASS, A., and HudlickA, O. (1964): Interrelations between Metabolism and Blood Flow in Normal and Denervated Dog Gastrocnemius Muscle at Rest and During Stimulation, Physiol. bohemoslov., 13, 48.

BroDy, I. A. (1964): The Significance of Lactate Dehydrogenase Isoenzymes in Abnormal Human Skeletal Muscle, Neurology (Minneap.), 14, 1091.

Chung, C. S., Morton, N. E., and Peters, H. A. (1960): Serum Enzymes and Genetic Carriers in Muscular Dystrophy, Amer. J. hum. Genet., 12, 52, COLOMBo, J. P., RICHTERICH, R., and Rossi, ho (1962): Serum Kreatin Phosphokinase: Bestine or mung und Diagnostische Bedeutung, Klin. Wschr 40, 37.

Dawson, D. M., Goodfriend, T. L., and KaplaN, N. O. (1964): Lactic Dehydrogenases: Functions of the Two Types, Science, 143, 929.

de Moragas, J. M., Perry, H. O., and Fleicher, G. A. (1957): Serum Glutamic Oxalacetic Transaminase in Dermatomyositis, J. Amer. med. Ass., 165, 1936.

Dreyfus, J. C., Demos, J., Schapira, F., and SCHAPIRA, G. (1962): La Lacticodéshdyrogenase Musculaire chez le Myopathe: Persistance Apparente du Type Foetal, C.R. Acad. Sci. (Paris), 254, 4385.

Dreyfus, J. C., and Schapira, G. (1962): Biochemistry of Hereditary Myopathies, Springfield, Illinois: Charles C. Thomas.

Dreyfus, J. C., Schapira, G., and Demos, J. (1960): Etude de la Créatine Kinase Sérique chez les Myopathies et Leurs Familles, Rev. franç. Etud. clin. biol., 5, 384.

Dreyfus, J. C., Schapira, G., and Schapira, F. $\frac{7}{0}$ (1958): Serum Enzymes in the Physiopathology of Muscle, Ann. N.Y. Acad. Sci., 75, 235.

Dreyfus, J. C., Schapira, G., Schapira, F., and 0 DEMOS, J. (1956): Activités Enzymatiques du $\mathrm{N}$ Muscle Humain. Recherches sur la Biochimie $N$ Comparée de l'Homme Normal et Myopathique $\omega$ et du Rat, Clin. chim. Acta, 1, 434.

Dubowitz, V. (1960): Progressive Muscular 0 Dystrophy of the Duchenne Type in Females and its Mode of Inheritance, Brain, 83, 432.

Dubowitz, V., and Pearse, A. G. E. (1960): A Comparative Histochemical Study of Oxidative $T$ Enzymes and Phosphorylase Activity in Skeletal Muscle, Histochemie, 2, 105. 
Dubowitz, V., and Pearse, A. G. E. (1961): Enzymic Activity of Normal and Diseased Human Muscle: a Histochemical Study, J. Path. Bact., 81, 365.

Ebashi, S., ToYoKura, Y., MaMoI, H., and Sugita, H. (1959): High Creatine Phosphokinase Activity of Sera of Progressive Muscular Dystrophy Patients, J. Biochem. (Tokyo), 46, 103.

EMERY, A. E. H. (1963): Clinical Manifestations in Two Carriers of Duchenne Muscular Dystrophy, Lancet, i, 1126.

EMERY, A. E. H. (1964a): Lyonisation of the Xchromosome, Lancet, i, 884.

Emery, A. E. H. (1964b): Electrophoretic Pattern of Lactic Dehydrogenase in Carriers and Patients with Duchenne Muscular Dystrophy, Nature (Lond.), 201, 1044.

ENGEL, W. K., EYerman, E. L., and Williams; H. Z. (1963): Late-onset Type of Skeletal Muscle Phosphorylase Deficiency: a New Familial V'ariety with Completely and Partially Affected Subjects, New Engl. J. Med., 268, 135.

EvaNS, J. H., and BAKER, R. W. R. (1957): Serum Aldolase and the Diagnosis of Myopathy, Brain, 80, 557.

Fowler, W. M., Chowdhury, S. R., Pearson, C. M., GARDNER, G., and Bratton, R. (1962): Changes in Serum Enzyme Levels after Exercise in Trained and Untrained Subjects, J. appl. Physiol., 17, 943.

Fowler, W. M., and Pearson, C. M. (1964): Diagnostic and Prognostic Significance of Serum Enzymes II, Neurological Diseases other than Muscular Dystrophy, Arch. phys. Med., 45, 125.

FriedmaN, M. M., and LAPAN, B. (1958): Serum Aldolase in the Neonatal Period: including a Colorimetric Determination of Aldolase by Standardization with Dihydroxyacetone, J. lab. clin. Med., 51, 745.

Fritz, I. B., Davis, D. G., Holtrop, R. H., and DUNDEe, H. (1958): Fatty Acid Oxidation by Skeletal Muscle during Rest and Activity, Amer. J. Physiol., 194, 379.

Gautier, E., and RICHTERICH, R. (1963): Valeur Diagnostique d'Activités Enzymatique du Sérum en Paediatre II. Constance et Specificité des Anomalies Enzymatique, Helv. paediat. Acta, 18, 32.

Gergely, J. (1964): Biochemical Aspects of Muscle Structure and Function: in Disorders of Voluntary Muscle, p. 86, ed. J. N. Walton. London: J. \& A. Churchill.

GrIfFITHS, P. D. (1963): Creatine Phosphokinase Levels in Hypothyroidism, Lancet, i, 894.

Griffiths, P. D. (1964): Serum Levels of Creatine Phosphokinase, J. clin. Path., 17, 56.

Halonen, P. I., and KontTinen, A. (1962): Effect of Physical Excercise on Some Enzymes in the Serum, Nature (Lond.), 193, 942.

HEYCK, H., LAUDAHN, G., and LUDERS, C. J. (1963): Fermentaktivitätsbestimmungen in der Gesunden Menschlichen Muskulatur und bei Myopathien II. Enzymaktivitätsveränderungen in Muskel bei Dystrophia Musculorum Progressiva, Klin. Wschr., 41, 500 .

Hockaday, T. D. R., Downey, J. A., and MotTram, R. F. (1964): A Case of McArdle's Syndrome with a Positive Family History, J. Neurol. Neurosurg. Psychiat., 27, 186.

HugHes, B. P. (1962): A Method for the Estimation of Serum Creatine Kinase and its Use in Comparing Creatine Kinase and Aldolase Activity in Normal and Pathological Sera, Clin. chim. Acta, 7, 597.
Hughes, B. P. (1963a): Serum Enzyme Studies with Special Reference to the Duchenne Type Dystrophy. In Research in Muscular Dystrophy: The Proceedings of the Second Symposium January 1963, p. 167. London: Pitman Medical.

Hughes, B. P. (1963b): Serum Enzyme Changes in Muscle Disease and their Relation to Tissue Change, Proc. roy. Soc. Med., 56, 179.

LARNER, J., and Villar-Palasi, C. (1959): Enzymes in Glycogen Storage Myopathy, Proc. nat. Acad. Sci. (Wash.), 45, 1234.

LAurysSENS, M. G., LAuRYSSENS, M. J., and ZondaG, H. A. (1964): Electrophoretic Distribution Pattern of Lactate Dehydrogenase in Mouse and Human Muscular Dystrophy, Clin. chim. Acta, 9, 276.

LELOIR, L. F., and CARDINI, C. E. (1957): Biosynthesis of Glycogen from Uridine Diphosphate Glucose, J. Amer. chem. Soc., 79, 6340.

LeVENE, P. A., and KRISZTEller, L. (1909): Factors Regulating the Creatine Output in Man, Amer. J. Physiol., 24, 45.

Leyburn, P. Thomson, W. H. S., and Walton, J. N. (1961): An Investigation of the Carrier State in the Duchenne Type Muscular Dystrophy, Ann. hum. Genet., 25, 41.

Lilienthal, J. L. jun., Zierler, K. L., Folk, B. P., BuKA, R., and RILEY, M. J. (1950): A Reference Base and System for Analysis of Muscle Constituents, J. biol. Chem., 182, 501.

LoHMAN, K. (1934): Uber die Enzymatische Aufspaltung der Kreatin-phosphorsäure: Zugleich ein Beitrag zum Chemismus der Muskelkontraktion, Biochem. Z., $271,264$.

LYON, M. F. (1961): Gene Action in the Xchromosome of the Mouse (Mus musculus L.), Nature (Lond.), 190, 372.

MCARDLE, B. (1951): Myopathy Due to a Defect in Muscle Glycogen Breakdown, Clin. Sci., 10, 13.

MCARDLE, B. (1964): Metabolic and Endocrine Myopathies: In Disorders of Voluntary Muscle, p. 389, ed. J. N. Walton. London : J. \& A. Churchill.

Mellick, R. S., Mahler, R. F., and Hughes, B. P. (1962): McArdle's Syndrome: Phosphorylasedeficient Myopathy, Lancet, ii, 1045.

Mommaerts, W. F. H. M., IllingWorth, B., Pearson, C. M., Guillory, R. J., and Seraydarian, K. (1959): A Functional Disorder of Muscle Associated with the Absence of Phosphorylase, Proc. nat. Acad. Sci. (Wash.), 45, 791.

OpIe, L. H., Evans, J. R., and Renold, A. E. (1962): Fructose in McArdle's Syndrome, Lancet, ii, 358.

Pearce, G. W. (1964): Tissue Culture and Electron Microscopy in Muscle Disease: in Disorders of Voluntary Muscle, ed. J. N. Walton, p. 237. London: J. \& A. Churchill.

Pearce, J. M. S., Pennington, R. J., and Walton, J. N. (1964a): Serum Enzyme Studies in Muscle Disease I. Variations in Serum Creatine Kinase Activity in Normal Individuals, J. Neurol. Neurosurg. Psychiat., 27, 1.

Pearce, J. M. S., Pennington, R. J., and Walton, J. N. (1964b): Serum Enzyme Studies in Muscle Disease II. Serum Creatine Kinase in Muscular Dystrophy and in other Myopathic and Neuropathic Disorders, J. Neurol. Neurosurg. Psychiat., 27, 26.

Pearson, C. M. (1964): The Periodic Paralyses: Differential Features and Pathological Observations in Permanent Myopathic Weakness, Brain, 87, 341.

Pearson, C. M. (1964b): Polymyositis and Related Disorders: in Disorders of Voluntary Muscle, ed. J. N. Walton, p. 315. London: J. \& A. Churchill. 
Pearson, C. M., Fowler, W. M., and Wright, S. W. (1963): X-chromosome Mosaicism in Females with Muscular Dystrophy, Proc. nat. Acad. Sci. (Wash.), 50, 24.

PenNington, R. J. (1964): Biochemical Aspects of Muscle Disease: in Disorders of Voluntary Muscle, ed. J. N. Walton, p. 255. London: J. \& A. Churchill.

Plummer, D. T., Elliott, B. A., CoOKe, K. B., and WILkINSON, J. H. (1963): Organ Specificity and Lactate Dehydrogenase Activity I. The Relative Activities with Pyruvate and 2-oxobutyrate of Electrophoretically Separated Fractions, Biochem. J., 87, 416.

RICHTERICH, R., Rosin, S., AEBI, U., and Rossi, E. (1963): Progressive Muscular Dystrophy V. The Identification of the Carrier State in the Duchenne Type by Serum Creatine Kinase Determination, Amer. J. hum. Genet., 15, 133.

Robbins, P. W., TraUt, R. R., and LipmanN, F. (1959): Glycogen Synthesis from Glucose, Glucose6-phosphate and Uridine Diphosphate Glucose in Muscle Preparations, Proc. nat. Acad. Sci. (Wash.), 45, 6.

RONZONI, E., BERG, L., and LANDAU, W. (1961): Enzyme Studies in Progressive Muscular Dystrophy, Res. Publ. Ass. nerv. ment. Dis., 38, 721.

Rowland, L. P., FAHN, S., and SChOtLand, D. L. (1963): McArdle's Disease: Hereditary Myopathy due to Absence of Muscle Phosphorylase, Arch. Neurol. (Chic.), 9, 325.

Saito, M., Hibi, I., Kawazura, M., and Fukuyama, Y. (1963): Creatine Phosphokinase Levels in Hypothyroidism, Lancet, ii, 252.

SCHAPIRA, G., and DREYFus, J. C. (1963): Biochemistry of Progressive Muscular Dystrophy: in Muscular Dystrophy in Man and Animals, ed. G. H. Bourne and N. Gollarz, p. 48. Basel: Karger.

SCHAPIRA, F., DREYFUS, J. C., SCHAPIRA, G., and Demos, J. (1960): Etude de l'aldolase et de la Creatine Kinase du Sérum chez les Mères de Myopathes, Rev. franç. Etud. clin. biol., 5, 990.

SchlaNG, H. A. (1961): Effect of Physical Exercise on Serum Transaminase, Amer. J. med. Sci., 242, 338.

SCHMID, R., and HAMmakeR, L. (1961): Hereditary Absence of Muscle Phosphorylase (McArdle's Syndrome), New Engl. J. Med., 264, 223.

SCHMID, R., and Marler, R. (1959): Chronic Progressive Myopathy with Myoglobinuria: Demonstration of a Glycogenolytic Defect in the Muscle, J. clin. Invest., 38, 2044.

Sibley, J. A., and LeHNINGER, A. L. (1949): Aldolase in Serum and Tissues of Tumour-bearing Animals, J. nat. Cancer Inst., 9, 303.

Slater, E. C. (1960): Biochemistry of Sarcosomes: in The Structure and Function of Muscle, ed. G. H. Bourne, p. 114. London: Academic Press.

SolvonUK, P. F., MCRAe, S. C., and Collier, H.B. (1956): Creatine Phosphokinase Activity of Mammalian Erythrocytes, Canad. J. Biochem., 34, 481.

Stein, J. M., and Padykula, H. A. (1962): Histochemical Classification of Individual Skeletal
Muscle Fibres of the Rat, Amer. J. Anat., 110, 163.

SteTten, D., JUN., and STETTEN, M. R. (1960): Gly- 乞 cogen Metabolism, Physiol. Rev., 40, 505.

SuTHERLAND, E. W., and WosilaIT, W. D. (1956): Ф The Relation of Epinephrine and Glucagon to liver $c$ Phosphorylase. I. Liver Phosphorylase; Preparation and Properties, J. biol. Chem., 218, 459.

Thompson, R. A., and Vignos, P. J. (1959): Serum Aldolase in Muscle Disease, Arch. intern. Med., 103, 551 .

ThOMSON, W. H. S. (1962): Sources of Error in the Biochemical Diagnosis of Muscular Dystrophy, J. Neurol. Neurosurg. Psychiat., 25, 191.

Thomson, W. H. S., LeYbuRN, P., and WALton, J. N. थै (1960): Serum Enzyme Activity in Muscular Dystrophy, Brit. med. J., ii, 1276.

Thomson, W. H. S., Maclaurin, J. C., and Prinias, $\vec{A}$ J. W. (1963): Skeletal Muscle Glycogenosis: an $\vec{\omega}$ Investigation of Two Dissimilar Cases, J. Neurol. Neurosurg. Psychiat., 26, 60.

VAN BREEMEN, V. L. (1960): Ultrastructure of Human 3 Muscle II. Observations on Dystrophic Striated is Muscle Fibres, Amer. J. Path., 37, 333.

VAN DEN BOSCH, J. (1963): Investigations of the $A$ Carrier State in the Duchenne Type Dystrophy. of Research in Muscular Dystrophy. The Proceedings $\omega$ of the Second Symposium January 1963, p. 23, $\vec{\omega}$ London: Pitman Medical.

Van PILsum, J. F., and Wolin, E. A. (1958): Guanidinium Compounds in Blood and Urine of Patients Suffering from Muscle Disorders, J. Lab. clin. Med., 51, 219.

VignOS, P. J., JUN., and LeFKowitz, M. (1959): A Biochemical Study of Certain Skeletal Muscle $\vec{\theta}$ Constituents in Human Progressive Musculam o Dystrophy, J. clin. Invest., 38, 873.

Walton, J. N. (1963): Clinical Aspects of Huma Muscular Dystrophy: in Muscular Dystrophy in Man and Animals, ed. G. H. Bourne and N. Golarz, p. 263, Basel: Karger.

Walton, J. N. (1964): Progressive Muscular Dys- 을 trophy: in Disorders of Voluntary Muscle, ed. ¿ J. N. Walton, p. 286, London: J. \& A. Churchill. $\overrightarrow{\vec{B}}$

WaTTS, D. C., and Hooton, B. J. (1965): Some Properties of Purified Creatine Kinase from the Skeletal Muscles of normal and Dystrophic Bar Harbor Mice. Research in Muscular Dystrophy: The Proceedings of the Third Symposium January 1965. London: Pitman Medical, in the press.

WhITE, L. P. (1959): Serum Enzymes. Variations of Activity in Disease of Muscle, Calif. Med., 80, 1 .

WIEME, R. J. (1959): Thesis: Studies on Agar Gel Electrophoresis. Brussels.

Wilson, K. M., Evans, K. A., and Carter, C. O. (1965): Creatine Kinase Levels in Women who Carry Genes for Three Types of Muscular Dystrophy, Brit. med. J., i, 750.

Wolf, H. P. (1962): Fructose in McArdle's Syndrome, Lancet ii, 937.

ZIERLER, K. L. (1958): Increased Muscle Perme- o ability to Aldolase Produced by Depolarization and $\mathrm{N}$ by Metabolic Inhibitors, Amer. J. Physiol., 193, 534. 